\title{
Assessment of the DNA Damage in Human Sperm and Lymphocytes Exposed to the Carcinogen Food Contaminant Furan with Comet Assay
}

\author{
Dilek Pandir* \\ Bozok University Faculty od Arts and Science - Biology, divanllyolu yozgat - Turkey
}

\begin{abstract}
The aim of this work was to assess the damage of DNA in human blood cell and sperm in vitro under the influence of furan. These cells were administered 0-600 $\mu \mathrm{M}$ of furan at 37 and $32^{\circ} \mathrm{C}$ for 30 and 60 min, respectively. A significant increase in tail DNA\%, tail length and moment indicating DNA damage was observed at increasing doses when compared to the controls. The treatment with 300 and $600 \mu M$ of furan showed a maximum increase of $86.74 \pm 2.43$ and $93.29 \pm 8.68$ compared to the control tail DNA\% in lymphocytes. However, only $600 \mu M$ of furan showed a maximum increase of $94.71 \pm 6.24$ compared to the control tail DNA\% in sperm. The results suggested that furan caused DNA damage in lymphocytes at increasing doses, but appeared to have not the same effect on human sperm at the low doses. Genotoxic activity had an impact on the risk assessment of furan formed on the food for human cells. Therefore, it would be important to further investigate these properties of furan as the food mutagen.
\end{abstract}

Key words: Furan, tail length, DNA damage, Human blood cells, Comet assay

\section{INTRODUCTION}

Furan $\left(\mathrm{C}_{4} \mathrm{H}_{4} \mathrm{O}\right)$ is the main compound of many chemicals used in several industrial sectors. This is a volatile, colorless liquid with a low boiling point (Maga, 1979; NTP, 1993). Furan and its derivatives occur naturally in many kinds of foods that undergo heat treatment such as canned and jarred foods, including baby foods and infant formula, and beverages such as coffee at the highest level (US Food and Drug Administration, 2004). Furan is formed by different routes: thermal degradation of carbohydrates only, or with some amino acids (this reaction is called, the Maillard reaction), thermal degradation of certain amino acids, or ascorbic acid and related compounds, and thermal degradation of polyunsaturated fatty acids and carotenoids (Becalski and Seaman, 2005; Yaylayan, 2006). It has been reported that ascorbic acid has the highest potential for furan production (Locas and Yaylayan, 2004; Fan, 2005, Karacaoglu et al. 2012).

The International Agency for Research on Cancer (IARC) has classified furan as a possible human carcinogen (Group 2B) (IARC, 1995a). Furan has also been known as hepatoxic and carcinogenic in the rats and mice by the National Toxicology Program (NTP) (NTP, 1993). Liver DNA damage was detected by comet in mice given a single dose of $250 \mathrm{mg} / \mathrm{kg}$ furan (Cordelli et al. 2010) and the $30 \mathrm{mg} / \mathrm{kg}$ dose was clearly detected toxic in the liver comet assay (Mc Daniel et al. 2012). There is evidence, however, that furan may damage liver

*Author for correspondence: durak77@gmail.com 
DNA indirectly through the generation of reactive oxygen species (Hickling et al. 2010).

Many chemical and physical agents found in the work-place and environment could be considered as reproductive toxins (Babazadeh et al. 2010). Furan treatment also induced toxicity to the reproductive system of male rats from weaning through postpuberty (Karacaoglu and Selmanoglu 2010).

The DNA is the critical target for lethal, carcinogenic, teratogenic and mutagenic effects of ionizing radiation and other environmental mutagens. There has always been a need to develop fast and sensitive methods for monitoring DNA damage, particularly in mammalian systems. Over the years, a number of biochemical methods based on alkaline sucrose gradients (Lett, 1970), alkaline elution (Kohn 1976), alkaline unwinding (Rydberg, 1980), alkaline gel electrophoresis (Freeman 1986), and the single-cell gel electrophoresis (SCGE) (Singh et al. 1988) have been developed for monitoring the DNA single strand breaks (Chaubey et al. 2001). Single cell gel electrophoresis (SCGE) assay, or comet test is a very simple, rapid, and sensitive technique for measuring the DNA damage (Singh et al. 1988; Fairbairn et al. 1995; Demir et al. 2011; Demir 2012; Demir and Kaya 2013; Demir et al. 2014). In this method, a small number of cells suspended in a thin agarose gel on a microscope slide are lysed, electrophoresed and stained with a fluorescent DNA finding dye. The technique is based on the fact that broken DNA migrates more easily in an electric field than the intact molecules. When the slide is visualized with a fluorescence microscope, the observed objects resemble comets with a head region containing undamaged DNA and a tail containing the broken DNA. The amount of DNA is able to migrate and the distance of migration indicate the number of strand breaks present in that cell. Greater migration of the chromosomal DNA from the nucleus is an indication of higher level of DNA damage (Singh et al. 1988; Rahman et al. 2002).

Comet assay is a genotoxicity testing method widely applied, both in vivo and in vitro, to different organs and tissues. This method can be applied to non-proliferating cells and for this reason, it is one of the few cytogenetic assays applicable to detect DNA damage induced in vitro on mature spermatozoa (Villani et al. 2010). Mutagens such as diethylsulfate, mitomycin C, bleomycin and colchicine have been tested on the treating mammalian sperm with comet assay in vitro (Villani et al. 2010). The effects of antioxidants and various other modifying agents on oxygen-radical-generated DNA damage in human lymphocytes have been investigated using the comet assay by Anderson et al. (1994). In other study, benzene and five of its known metabolites-muconic acid, hydroquinone, catechol, p-benzoquinone, and benzentriol-were examined for DNA damage in human lymphocytes using the alkaline comet assay (Anderson et al. 1995). Because of the limitations of in vitro assays for assessing the genotoxicity of furan, information about the genotoxicity of furan in the sperm and lymphocytes might not be enough. Thus, in the present investigation, experiments were conducted in human blood cell and sperm in vitro to determine the dose response for DNA damage by furan using the comet assay.

\section{MATERIAL AND METHODS}

\section{Chemicals}

Furan (CAS no. 110-00-9) (99\% pure) was obtained from Sigma-Aldrich Chemical Co. and mixed with Mazola corn oil. RPMI 1640 was bought from Sigma-Aldrich, Germany. Proteinase K was obtained Roche Diagnostics, Germany. All other reagents and chemicals used were of analytical grade.

\section{Blood and sperm samples}

Heparinised blood samples $(10 \mathrm{~mL})$ were obtained by venepuncture from a healthy a 25 -year-old male donor. Lymphocytes were isolated from the whole blood [using lymphoprep (Axis Sheild, Oslo Norway)] and aliquots were stored in liquid nitrogen. The cells were treated for $30 \mathrm{~min}$ with the different doses of furan and re-suspended in RPMI-1640 for analysis $\left(2 \times 10^{5}\right.$ cells $\left./ \mathrm{mL}\right)$ (Anderson et al. 1994; 2003). Treated cells were suspended in low melting point agarose $(0.65 \%)$, and $75 \mu \mathrm{L}$ of suspension was quickly layered over the slides, which were precoated with normal melting point agarose $(0.65 \%)$, then immediately covered with a cover slip and the slides were placed on $4{ }^{\circ} \mathrm{C}$ for $15 \mathrm{~min}$. After solidification, the coverslip was gently removed and immersed in cold lysing solution $(2.5 \mathrm{M} \mathrm{NaCl}, 100 \mathrm{mM}$ EDTA, $10 \mathrm{mM}$ Tris $\mathrm{pH}=10$ in which $10 \%$ DMSO and $1 \%$ Triton X-100 were added) at $4{ }^{\circ} \mathrm{C}$ for $1 \mathrm{~h}$ (Pandir 2015). 
Semen was obtained from a 34-year-old male according to WHO criteria (WHO 2000): sperm number: $64 \times 10^{6} \mathrm{~mL}$; motility: $72 \%$; sperm morphology: abnormal forms: $25 \%$. Aliquots (10 $\mu 1$ sperm from aliquots frozen at $-80{ }^{\circ} \mathrm{C}$ ) were made up to $1.0 \mathrm{~mL}$ RPMI 1640 medium in an Eppendorf tube and incubated at $37{ }^{\circ} \mathrm{C}$ for $1 \mathrm{~h}$ (Anderson et al. 1997a, b). The procedure was then carried out as for the lymphocytes; however, just before the slides were placed in lysis solution, $0.05 \mathrm{mg} / \mathrm{mL}$ proteinase $\mathrm{K}$ was added to the lysis solution and the slides were placed at $37{ }^{\circ} \mathrm{C}$ overnight (Anderson et al. 2003).

The cells were checked for their viability before the start and after the completion of the experiment using trypan blue dye (Pool-Zobel et al. 1992). Preparation of the slides for the comet assay and subsequent electrophoresis, and staining were carried as previously described (Anderson et al., 1994) for the lymphocytes and the sperm (WHO 2000; Anderson et al. 1997a,b), using a modification of the methods of Singh et al. 1988, 1989. All the data were analyzed using BS 200 ProP with software image analysis (BS 200 ProP, BAB Imaging System, Ankara, Turkey). The DNA comets were evaluated by measuring the tail length, tail moment and tail DNA\% of 50 comets. All the experiments were performed at least three times, each with two parallel slides per data point. A higher percentage tail DNA\% and tail lenght indicated a higher level of DNA damage (Behravan et al. 2011).

\section{Statistics Analysis}

Differences between the groups were evaluated by one-way analysis of variance (ANOVA), followed by the Tukey test. Values were expressed as mean \pm standard error of the mean (SEM). Statistical significance was accepted at the $p<0.05$ level.

\section{RESULTS}

The results of DNA damage of lymphocytes and sperm obtained after the treatment by furan are summarized in Figures 1-5 and and Table 1.

There were no differences in DNA damage between the cell of lymphocytes that were treated with $100 \mu \mathrm{M}$ furan as compared with the untreated control cells. DNA strand breaks showed clear dose response between the DNA damage and different doses of furan $(300$ and $600 \mu \mathrm{M})$. The tail DNA\% and tail length induced by the increasing doses of furan were significantly $(\mathrm{p}<0.05)$ higher than that of the controls. The treatment with 300 and $600 \mu \mathrm{M}$ of furan showed a maximum increase of $86.74 \pm 2.43$ and $93.29 \pm 8.68$ compared to control tail DNA\% (Figs. 1A-1D, Table 1).

Sperm treated with furan only $600 \mu \mathrm{M}$ concentration exhibited more DNA damage compared to the un-treated sperm (Figs. 2A-2D). The tail DNA\% and values ranged from $66.00 \pm$ 5.99 to $94.71 \pm 6.24$ in the sperm (Table 1, Fig. 3), whereas mean tail length values ranged from $6.31 \pm$ 1.68 to $75.73 \pm 27.46$ (Table 1, Fig. 4). Doses of 100 and $300 \mu \mathrm{M}$ of furan produced similar result as that of control cells in tail DNA\% but higher increases in the tail DNA\% were observed only at $600 \mu \mathrm{M}$ for furan.

Table 1 - Dose-response of furan in human lymphocytes and sperm showing values of mean tail DNA\%, tail length and tail moment of comets. Superscript letters indicate significant differences among exposed to different doses of furan. Significance at $\mathrm{p}<0.05$.

\begin{tabular}{|c|c|c|c|}
\hline $\begin{array}{c}\text { Different exposure doses of } \\
\text { lymphocytes }\end{array}$ & $\begin{array}{c}\text { Tail DNA \% } \\
\text { Mean } \pm \text { SE }\end{array}$ & $\begin{array}{l}\text { Tail lenght } \\
\text { Mean } \pm \text { SE }\end{array}$ & $\begin{array}{l}\text { Tail moment } \\
\text { Mean } \pm \text { SE }\end{array}$ \\
\hline Control & $72.00 \pm 4.33^{\mathrm{a}}$ & $5.58 \pm 1.03^{\mathrm{a}}$ & $4.04 \pm 0.98^{\mathrm{a}}$ \\
\hline $100 \mu \mathrm{M}$ & $68.65 \pm 1.63^{\mathrm{a}}$ & $7.53 \pm 0.35^{\mathrm{a}}$ & $4.42 \pm 0.32^{\mathrm{a}}$ \\
\hline $300 \mu \mathrm{M}$ & $86.74 \pm 2.43^{\mathrm{ab}}$ & $20.88 \pm 13.05^{\mathrm{ab}}$ & $17.95 \pm 10.80^{\mathrm{ab}}$ \\
\hline $600 \mu \mathrm{M}$ & $93.29 \pm 8.68^{\mathrm{abc}}$ & $61.89 \pm 38.10^{\mathrm{abc}}$ & $59.39 \pm 40.92^{\mathrm{abc}}$ \\
\hline $\begin{array}{c}\text { Different exposure doses of } \\
\text { sperm }\end{array}$ & $\begin{array}{l}\text { Tail DNA\% } \\
\text { Mean } \pm \text { SE }\end{array}$ & $\begin{array}{l}\text { Tail lenght } \\
\text { Mean } \pm \text { SE }\end{array}$ & $\begin{array}{l}\text { Tail moment } \\
\text { Mean } \pm \text { SE }\end{array}$ \\
\hline Control & $54.37 \pm 11.65^{\mathrm{a}}$ & $6.21 \pm 2.09^{\mathrm{a}}$ & $3.50 \pm 1.87^{\mathrm{a}}$ \\
\hline $100 \mu \mathrm{M}$ & $66.00 \pm 5.99^{\mathrm{a}}$ & $6.31 \pm 1.68^{\mathrm{a}}$ & $4.23 \pm 1.42^{\mathrm{b}}$ \\
\hline $300 \mu \mathrm{M}$ & $69.62 \pm 7.09^{\mathrm{a}}$ & $10.52 \pm 1.71^{\mathrm{a}}$ & $7.35 \pm 1.65^{\mathrm{c}}$ \\
\hline $600 \mu \mathrm{M}$ & $94.71 \pm 6.24^{\mathrm{abc}}$ & $75.73 \pm 27.46^{\mathrm{abc}}$ & $70.87 \pm 21.29^{\mathrm{abc}}$ \\
\hline
\end{tabular}




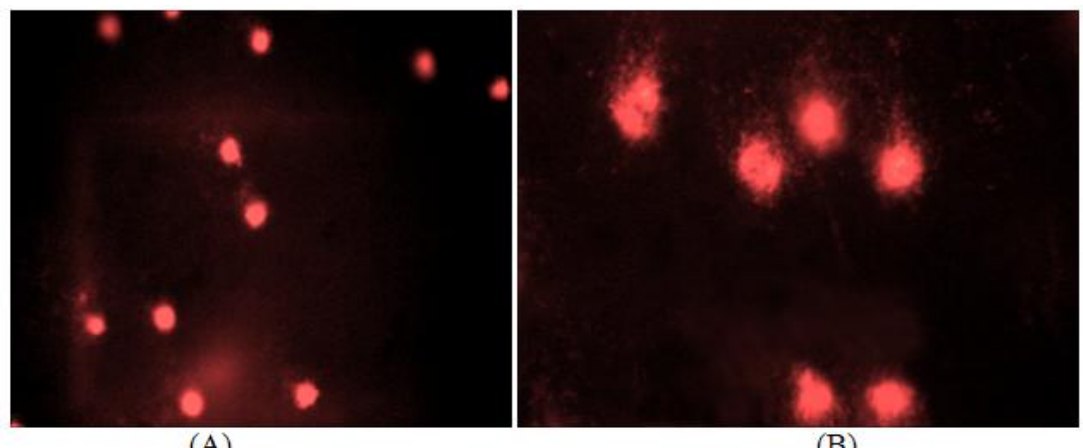

(A)

(B)

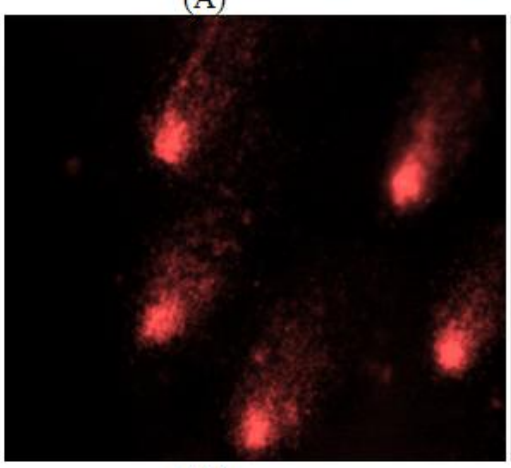

(C)

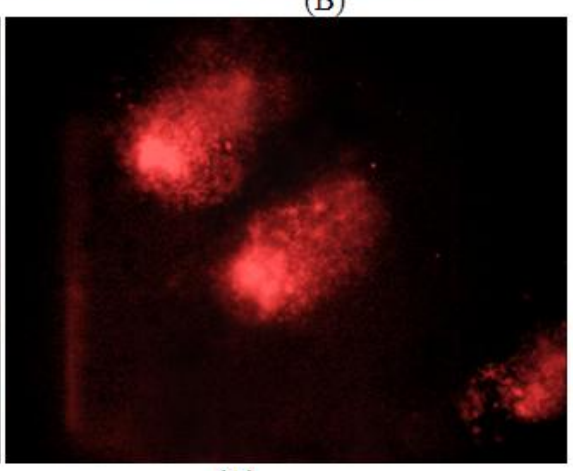

(D)

Figure 1- Image analysis on different exposure doses of furan treatment groups and control group in human lymphocytes (A) Control DNA of lymphocytes (B) $100 \mu \mathrm{M}$ - (C) $300 \mu \mathrm{M}$ - (D) 600 $\mu \mathrm{M}$-exposure furan in lymphocytes DNA damage.

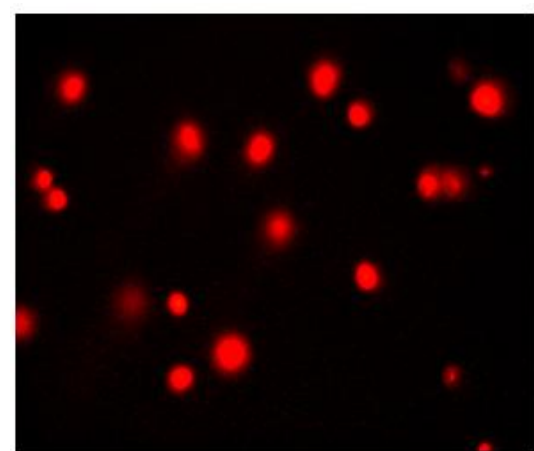

(A)

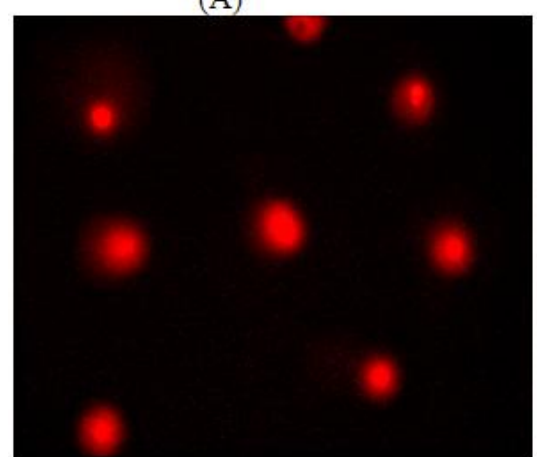

(C)

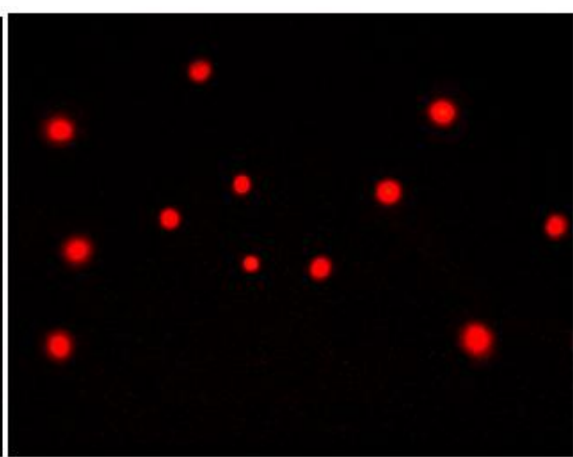

(B)

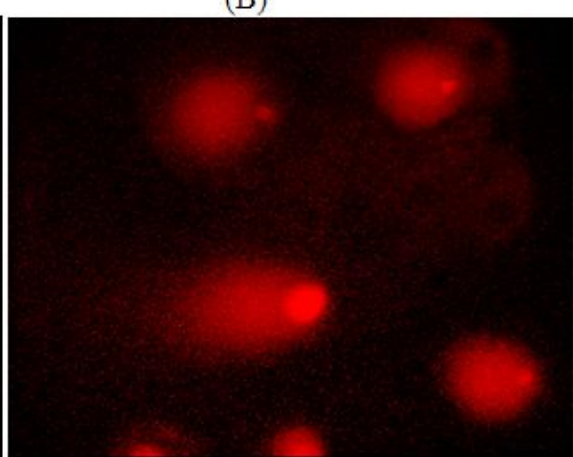

(D)

Figure 2 - Image analysis on different exposure doses of furan treated group and control group in human sperm (A) Control DNA of sperm (B) $100 \mu \mathrm{M}$ - (C) $300 \mu \mathrm{M}$ - (D) $600 \mu \mathrm{M}$ exposure furan in sperm DNA damage. 


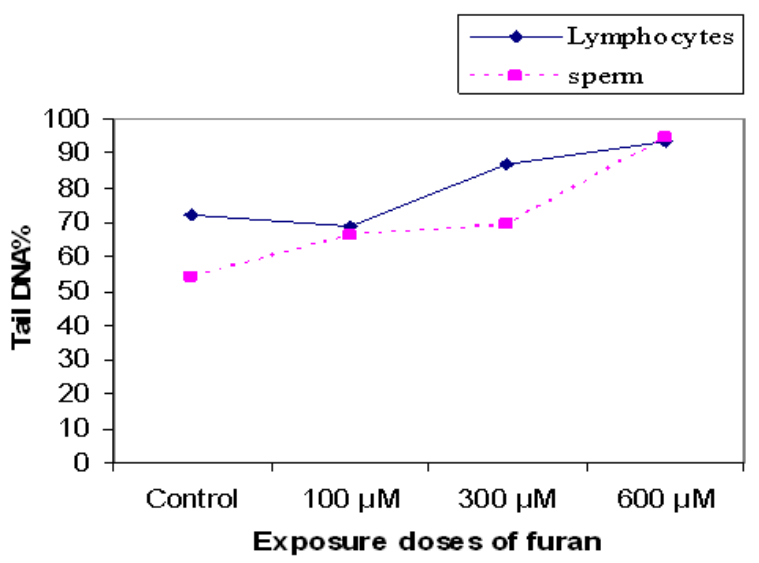

Figure 3 - Changes of comet tail DNA\% with exposure increasing doses of furan in lymphocytes and sperm.

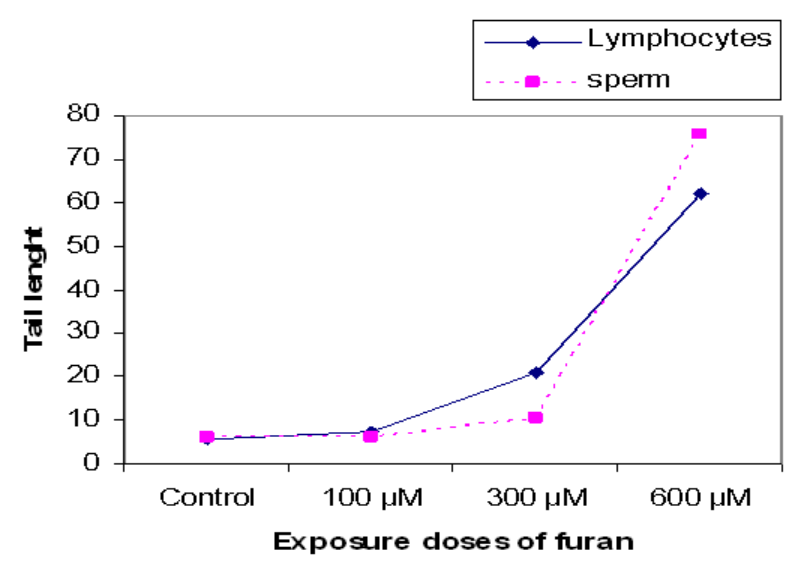

Figure 4 - Changes of comet tail length with exposure increasing doses of furan in lymphocytes and sperm.

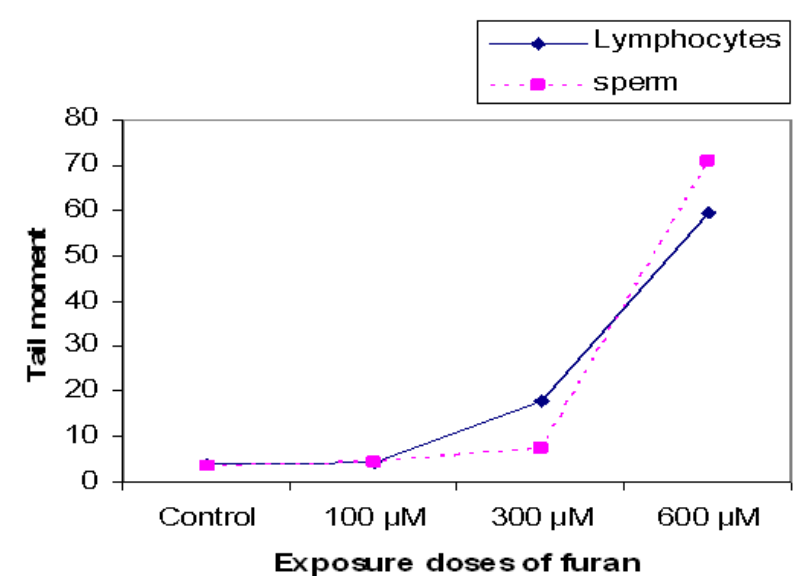

Figure 5 - Changes of comet tail moment with exposure increasing doses of furan in lymphocytes and sperm.

\section{DISCUSSION}

Furan is a small heterocycle that, as a pure substance, is a colorless, relatively volatile liquid. It is used industrially as a solvent and as an intermediate in chemical syntheses with little indication of worker exposure (IARC 1995b). It, however, is also generated as a combustion product released into the air in the gas phase of cigarette smoke. More importantly, furan has been detected in many common cooked foods, where concentrations over $100 \mathrm{ppb}$ have been detected (U.S. FDA, 2011a,b; McDaniel et al. 2012). Therefore, this study was planned to find the genotoxic potential increasing doses $(100,300$ and $600 \mu \mathrm{M})$ of furan in human peripheral lymphocytes and sperm in vitro since such assays have not been carried out previously.

A number of techniques for detecting the DNA damage, other than to those of biological effects (e.g., micronuclei, mutations, structural chromosomal aberrations) that result from the DNA damage, have been used to identify the substances with genotoxic activity (Tice et al. 2000). As a test for the genotoxicity, the comet assay can be used to identify possible human mutagens and carcinogens (Anderson et al. 1998a). Anderson et al. (2003) examined human sperm and lymphocytes after the treatment with six oestrogenic compounds in the comet assay, which measured the DNA damage, and observed that all caused damage in both cell types. Free radical production at the levels comparable to those that may induce capacitation in vivo and can also cause DNA damage. Increasing oxidative stress by oestrogenic compounds over and above the levels of ROS, which may already be present in the cells could probably have adverse effects in terms of capacitation and defective sperm and lymphocyte function (Anderson et al. 2003). In another study, a number of analogues of cryptolepine were synthesised in an attempt to find the compounds that reduced cytotoxicity and these were investigated in human sperm and lymphocytes using the comet assay (Gopalan et al. 2011). Anderson et al. (1998b) examined some flavonoids in combination with the food mutagens, 3-amino-1-methyl-5H-pyrido (4,3-b)indole (TrpP-2) and 2-amino-3-methylimidazo-(4,5-f) quinoline (IQ), in the comet assay in human lymphocytes from donor $\mathrm{A}$ and human sperm from donor B. These compounds showed alone to produce positive responses in the comet assay, as 
the food mutagens. In this study the standard alkaline comet assay was used to detect furaninduced DNA strand breaks in human lymphocytes and sperm.

Clear differences between the treated and nontreated samples were observed (Table 1). The changes of comet tail DNA\%, tail length and tail moment with applied doses evaluated the results of comets by image analysis. Furan increased the comet tail DNA\%, tail length and tail moment at increasing treatment concentrations in a concentration-dependent manner compared with the control in lymphocytes, but a significant increase was observed in these parameters in concentration of only highest dose of furan treatment in sperm. Results obtained in this and in the other studies mentioned above showed that furan was DNA damaging chemical. It could lead to the formation of DNA single and/or double strand breaks as other chemicals.

Oxidative DNA damage is a biomarker of oxidative stress, which is a possible causative factor in the production of cancer (Klaunig et al. 1998). Genotoxicity induced by the oxidative stress is produced indirectly, and may not result in the same dose responses for genotoxicity, or cancer as produced by an agent that interacts directly with the DNA (EPA, 2007). Thus, it would be important to fully define whether, or not any genotoxicity produced by furan was through the generation of oxidative DNA damage, or as a result of its direct interaction with the DNA (Ding et al. 2012). The present study used the in vitro comet assay to evaluate the DNA damage, including oxidative DNA damage produced by increasing doses of furan in human lymphocytes and sperm.

\section{CONCLUSION}

Standard alkaline comet assay was used to detect furan-induced DNA strand breaks in these cells. Lymphocytes and sperm were metabolically active after the treatment with different mutagens and sensitive to oxygen radical damage. Furan also generated reactive oxygen species in lymphocytes and sperm and caused DNA damage directly. Thus, furan showed genotoxic potential. These findings supported the hypothesis that different doses of furan could influence the other living cells of human. The results supported further investigation on the toxicity induced by furan using the comet assay.

\section{ACKNOWLEDGEMENTS}

The author would like to thank to Esra GUVEN for helping to prepare this study.

\section{REFERENCES}

Anderson D, Basaran N, Dobrzynska M, Basaran AA, $\mathrm{Yu}$ TW. Modulating effects of flavonoids on food mutagens in human blood and sperm in the Comet assay. Teratog Carcinog Mutagen. 1997a; 17: 45-58.

Anderson D, Dobrzynska MM, Basaran N. Effect of various genotoxins and reproductive toxins in human lymphocytes and sperm in the Comet assay. Teratog Carcinog Mutagen. 1997b; 17 (1): 29-43.

Anderson D, Dobrzyńska MM, Basaran N, Basaran A, $\mathrm{Yu}$ TW. Flavonoids modulate Comet assay responses to food mutagens in human lymphocytes and sperm. Mutat Res. 1998a; 402: 269-277.

Anderson D, Schmid TE, Baumgartner A, CemeliCarratala E, Brinkworth MH, Wood JM, et al. Oestrogenic compounds and oxidative stress (in human sperm and lymphocytes in the comet assay). Mutat Res. 2003; 544: 173-178.

Anderson D, Yu TW, McGregor DB. Comet assay responses as indicators of carcinogenic exposure. Mutagen. 1998b; 13:539 -555.

Anderson D, Yu TW, Phillips BJ, Schmezer P. The effect of various antioxidants and other modifying agents on oxygen-radical-generated DNA damage in human lymphocytes in the comet assay. Mutat Res. 1994 ; 307(1): 261-271.

Anderson D, Yu TW, Schmezer P. An investigation of the DNA-damaging ability of benzene and its metabolites in human lymphocytes, using the comet assay. Environ Mol Mutagen. 1995; 26(4): 305-314.

Babazadeh Z, Razavi S, Tavalaee M, Mohammad RDMR, Shahidi M, Nasr-Esfahani MH, et al. Sperm DNA damage and its relation with leukocyte DNA damage. Reprod Toxicol. 2010; 29: 120-124.

Becalski A, Seaman S. Furan precursors in food: a model study and development of a simple headspace method for determination of furan. J Assoc Offic Anal Chem. 2005; 88: 102-106.

Behravan J, Mosafa F, Soudmand N, Taghiabadi E, Razavi BM, Karimi G, et al. Protective effects of aqueous and ethanolic extracts of Portulaca oleracea L. aerial parts on $\mathrm{H}_{2} \mathrm{O}_{2}$ - induced DNA damage in lymphocytes by comet assay. Acupunct Meridian Stud. 2011; 4: 193-197. 
Chaubey RC, Bhilwade HN, Rajagopalan R, Bannur SV. Gamma ray induced DNA damage in human and mouse leucocytes measured by SCGE-Pro: a software developed for automated image analysis and data processing for Comet assay. Mutat Res. 2001; 490: 187-197.

Cordelli E, Leopardi P, Villani P, Marcon F, Macri C, Caiola $\mathrm{S}$, et al. Toxic and genotoxic effects of oral administration of furan in mouse liver. Mutagen. 2010; 25: 305-314.

Demir E, Kaya N, Kaya B. Evaluation of DNA damage in Capsicum annuum L. exposed to spinosad in the comet assay. Fresen Environ Bull. 2011; 20: 19261930.

Demir E. In vivo genotoxicity assessment of diflubenzuron and spinosad in Drosophila melanogaster with the comet assay using haemocytes and the SMART assay. Fresen Environ Bull. 2012; 21: 3894-3900.

Demir E, Kaya B. Studies on the genotoxic properties of four benzyl derivatives in the in vivo comet assay using haemocytes of Drosophila melanogaster. Fresen Environ Bull. 2013; 22: 1590-1596.

Demir E, Kaya N, Kaya B. Genotoxic effects of zinc oxide and titanium dioxide nanoparticles on root meristem cells of Allium cepa by comet assay. Turk $J$ Biol. 2014; 38: 31-39.

Ding W, Petibone DM, Latendresse JR, Pearce MG, Muskhelishvili L, White GA, et al. In vivo genotoxicity of furan in F344 rats at cancer bioassay doses. Toxicol Appl Pharm. 2012; 261: 164-171.

EPA, Framework for Determining a Mutagenic Mode of Action for Carcinogenicity: Using EPA's 2005 Cancer Guidelines and Supplemental Guidance for Assessing Susceptibility from Early-Life Exposure to Carcinogens. EPA 120/R-07-002-A. 2007. http://www.epa.gov/osa/mmoaframework/pdfs/MMO A-ERD-FINAL-83007.pdf

Fairbairn DW, Olive PL, O'Neill KL. The comet assay: a comprehensive review. Mutat Res. 1995; 339: 3759.

Fan X. Formation of furan from carbohydrates and ascorbic acid following exposure to ionizing radiation and thermal processing. J Agric Food Chem. 2005; 53: 7826-7831.

Freeman SE, Blackett AD, Monte Leone DC, Setlow RB, Sutherland BM, Sutherland JC, et al. Quantitation of radiation-, chemical-, or enzyme induced single strand breaks in non radioactive DNA by alkaline gel electrophoresis: application to pyrimidine dimers. Anal Biochem. 1986; 158: 119129.

Gopalan RC, Emerce E, Wright CW, Karahalil B, Karakaya AE, Anderson D, et al. Effects of the antimalarial compound cryptolepine and its analogues in human lymphocytes and sperm in the Comet assay. Toxicol Lett. 2011; 207: 322-325.
Hickling KC, Hitchcock JM, Oreffo V, Mally A, Hammond TG, Evans JG, et al. Evidence of oxidative stress and associated DNA damage, increased proliferative drive, and altered gene expression in rat liver produced by the cholangiocarcinogenic agent furan. Toxicol Pathol. 2010; 38: 230-243.

IARC-International Agency for Research on Cancer IARC monographs on the evaluation of carcinogenic risks to humans, dry cleaning, some chlorinated solvents and other industrial chemicals. France: Lyon. 1995a. vol. 63, pp. 3194-3407.

IARC (International Agency for Research on Cancer), Dry cleaning, furan, in: IARC Monographs on the Evaluation of Carcinogenic Risks to Humans, Some Chlorinated Solvents and other Industrial Chemicals, IARC, Lyon, 1995b. vol. 63, pp. 393-407.

Karacaoglu E, Selmanoglu G. Effects of heat-induced food contaminant furan on reproductive system of male rats from weaning through postpuberty. Food Chem Toxicol. 2010; 48: 1293-1301.

Karacaoglu E, Selmanoglu G, Kılıç A. Histopathological effects of the food contaminant furan on some endocrine glands of prepubertal male rats. Turk J Med Sci. 2012; 42 (1): 1207-1213.

Klaunig JE, Xu Y, Isenberg JS, Bachowski S, Kolaja KL, Jiang $\mathrm{J}$, et al. The role of oxidative stress in chemical carcinogenesis. Environ Health Perspect. 1998; 106 (1): 289-295.

Kohn KW, Erickson LC, Ewig RA, Friedman CA. Fractionation of DNA from mammalian cells by alkaline elution. Biochem. 1976; 15: 4629-4637.

Lett JT, Klucis ES, Sun C. On the size of the DNA in mammalian chromosomes. Biophys J. 1970; 10: 277 292.

Locas CP, Yaylayan VA. Origin and mechanistic pathways of formation of the parent furan-a food toxicant. J Agric Food Chem. 2004; 52: 6830-6836.

Maga JA. Furans in foods. CRC Cr Rev Food Sci 1979; 355-399.

McDaniel LP, Ding W, Dobrovolsky VN, Shaddock Jr JG, Mittelstaedt RA, Doerge DR, et al. Genotoxicity of furan in Big Blue rats. Mutat Res. 2012; 742: 7278.

National Toxicology Program (NTP) Toxicology and Carcinogenesis Studies of Furan in F-344/N Rats and B6C3F1 Mice. In: NTP Technical Report No. 402, US Department of Health and Human Services, Public Health Service, National Institute of Health, Research Triangle Park, NC, USA. 1993.

Pandir D. Protective effect of (-)-epigallocatechin-3gallate on capsaicin-induced DNA damage and oxidative stress in human erythrocytes and leucocytes in vitro. Cytotechnol. 2015; 67(2):367-377. 
Pool-Zobel BL, Klein RG, Leigebel UM, Kuchenmeister F, Weber S, Schmezer P, et al. Systemic genotoxic effects of tobacco-related nitrosamines following oral and inhalation administration to Sprague-Dawley rats. Clin Invest. 1992; 70: 299-306.

Rahman MF, Mahboob M, Danadevi K, Saleha Banu B, Grover P. Assessment of genotoxic effects of chloropyriphos and acephate by the comet assay in mice leucocytes. Mutat Res. 2002; 516: 139-147.

Rydberg B. Detection of induced DNA strand breaks with improved sensitivity in human cells. Radiat Res. 1980; 81: 492-495.

Singh NP, Danner DB, Tice RR, Mc Coy MT, Collins GD, Schneider EL, et al. Abundant alkali-sensitive sites in DNA of human and mouse sperm. Exp Cell Res. 1989; 184: 461-470.

Singh NP, McCoy MT, Tice RR, Schneider EL. A simple technique for quantitation of low levels of DNA damage in individual cells. Exp Cell Res. 1988; 175: 184-191.

Tice RR, Agurell E, Anderson D, Burlinson B, Hartmann A, Kobayashi $\mathrm{H}$, et al. Single Cell Gel/Comet Assay: Guidelines for In vitro and In vivo genetic toxicology testing. Environ Mol Mutagen. 2000; 35: 206-221.
U.S. FDA (U.S. Food and Drug Administration), Exploratory Data on Furan in Food, Data Through April 28, 2004, http://www.fda.gov/ohrms/dockets/ac /04/briefing/4045b2 09 furan\%20data.pdf (accessed 8-21-2011a).

U.S. FDA (U.S. Food and Drug Administration), Exploratory Data on Furan in Food: Individual Food Products, Data Through September 17, 2008, http://www.fda.gov/Food/FoodSafety/FoodContamin antsAdulteration/ChemicalContaminants/Furan/ucm0 78439.htm (site accessed 8-3-2011b).

US Food and Drug Administration. 2004. Exploratory Data on Furan in Food. Washington, DC: FDA. Available at: http:// www.cfsan.fda.gov/about $\sim \mathrm{dms} /$ furandat.htmL.

Villani P, Spanò M, Pacchierotti F, Weimer M, Cordelli E. Evaluation of a modified comet assay to detect DNA damage in mammalian sperm exposed in vitro to different mutagenic compounds. Reprod Toxicol. 2010; 30: 44-49.

WHO. 2000. World Health Organization laboratory manual for the examination of human semen and sperm-cervical mucus interaction, Cambridge University Press, Cambridge, UK,

Yaylayan VA. Precursors, formation and determination of furan in foods. J Verbrauch Lebensm 2006; 1: 5-9. 